\title{
MONGOLIAN STUDENTS' DIGITAL LITERACY \\ PRACTICES: THE INTERFACE BETWEEN ENGLISH AND \\ THE INTERNET
}

\author{
PRÁTICAS DE LETRAMENTO DIGITAL DE ESTUDANTES DA \\ MONGÓLIA: A INTERFACE ENTRE O INGLÊS E A INTERNET
}

\section{Daariimaa Marav*}

\begin{abstract}
Over the last few decades, Mongolia has experienced social, economic, technological and political changes. Those changes have contributed to the growing cultural status of English mediated in particular through the digital literacy practices of young Mongolians. However, much of the digital and new media research takes place in predominantly AngloAmerican contexts (PRINSLOO \& ROWSELL, 2012) and not much is known about what shapes Mongolian university students' use of digital technologies. The research reported on here aims to fill this gap. Drawing on perspectives offered by the field of Literacy Studies, which analyses literacy practices within the social and cultural contexts in which they occur, and employing a mixed methods approach, the research examines how Mongolian university students majoring in English used digital technologies, especially the internet, in their everyday lives. Data were generated through a survey of 98 students and through observations of and interviews with six case study participants who came from diverse socioeconomic backgrounds. The findings indicate that most students' digital literacy practices were directed towards improving their English. They used digital technologies strategically by negotiating the issues of cost and time, and exercised agency in personalising the technologies to support their English learning and eventually to improve their social positions. However, the findings also suggest that the participants' engagement with digital technologies was shaped by contextual and structural factors which included family background, personal resources such as English proficiency, digital literacies and aspirations. The research considers how the findings may inform improvements to educational practices around the teaching and learning of English and digital literacies in Mongolian universities. Keywords: Mongolian university students; digital literacy practice; use of English.
\end{abstract}

\section{RESUMO}

Nas últimas décadas, a Mongólia tem sofrido mudanças sociais, econômicas, tecnológicas e politicas. Essas mudanças têm contribuído para o aumento do status cultural do inglês que circula nas práticas de letramento digital de jovens na Mongólia. Contudo, grande parte da pesquisa acerca da mídia digital é realizada predominantemente em contextos Anglo-Americanos (PRINSLOO \& ROWSELL, 2012) e pouco se conhece sobre o uso de

\footnotetext{
*National University of Mongolia, Mongolia. daariimaa.marav@gmail.com
} 
tecnologias digitais por parte de estudantes universitários mongóis. A pesquisa reportada aqui visa a suprir essa lacuna. Embasado em perspectivas oferecidas pelos Estudos dos Letramentos, que analisam praticas de letramentos em meio aos contextos sociais e culturais em que estas ocorrem, e apoiando em uma metodologia mista, o estudo investiga como graduandos em Inglês da Mongólia usaram as tecnologias digitais, em especial a internet, em suas vidas cotidianas. Os dados foram gerados por meio de um levantamento com 98 estudantes, além de observações e entrevistas atreladas a seis participantes ligados ao estudo de caso e que apresentavam diferentes perfis socioeconômicos. Os resultados indicam que a maior parte das práticas de letramentos digitais voltaram ao aperfeiçoamento do inglês. Os participantes utilizaram as tecnológicas estrategicamente, negociando questões relativas a custo e tempo, bem como exerceram agência na medida em que personalizaram as tecnologias para apoiar sua aprendizagem da língua e eventualmente para melhorar suas posições sociais. Em contrapartida, os resultados também sugerem que o envolvimento com as tecnologias digitais foi delineado por fatores estruturais e contextuais que incluem histórico familiar, recursos pessoais, tais como proficiência em inglês, letramentos digitais e aspirações. $\mathrm{O}$ presente trabalho pretende refletir sobre como os resultados da pesquisa podem contribuir com as práticas educacionais ligadas ao ensino-aprendizagem de inglês em sua interface com os letramentos digitais nas universidades da Mongólia.

Palavras-chave: estudantes universitários mongóis; práticas de letramentos digitais, uso do inglês.

\section{INTRODUCTION}

Geographically, Mongolia is located in Central Asia sandwiched between Russia and China. Mongolia is a vast country of 1.6 million square kilometres with a population of 3.06 million (NATIONAL STATISTICAL OFFICE OF MONGOLIA, 2016). In recent years Mongolia has been experiencing social, economic, technological and political changes that are directly related to the forces of globalisation. Central to the changes in Mongolia is the proliferation of digital technologies, computers and the internet. Digital literacies in tandem with English proficiency have become important for Mongolian students to ensure their future employment and full participation in the global information society. However, much of the digital and new media research takes place in predominantly Anglo-American contexts (PRINSLOO \& ROWSELL, 2012) and not much is known about what shapes Mongolian university students' use of digital technologies. Thus, the study reported in this paper aims to fill this gap.

As Koutsogiannis (2007) emphasises, digital literacy cannot be studied in isolation without reference to the parameters of modern reality and history: to understand the changing literacy practices of modern youth in Mongolia it is necessary to reflect on the changes in the country that have occurred over the last few decades, especially since 1990, when Mongolia moved from a socialist 
system to a democracy. One change has been that English language education has become very popular as evidenced in a number of government policy documents. For example, the policy associated with English teaching has been reformed several times aiming to improve the quality of English teaching by creating a favourable environment for learning the language (GOVERNMENT OF MONGOLIA, 2010). For instance, the National Policy on Improving the Quality of English Teaching (GOVERNMENT OF MONGOLIA, 2001) emphasises the need for improving the language skills of English teachers in Mongolia, increasing the number of teachers, particularly, in rural areas, facilitating language learning with teaching resources and using mass media, TV and radio to run English language courses. In tandem with the changes to the number of years of schooling in Mongolia, teaching and learning English at school increased to eight years - from grade 5 to grade 12 . Ten years of schooling were offered under socialism then increased to 11 in 2006 and to 12 in 2008 (GOVERNMENT OF MONGOLIA, 2010).

However, as English had rarely been offered under socialism, there was a shortage of English teachers when the language began to be studied in schools. This meant that the Mongolian government's first goal was to retrain former Russian teachers through intensive English courses so that they could teach English (FORSETH \& FORSETH, 1996). Approximately 400 Russian language teachers were re-trained as English teachers by the beginning of the 2000s (COHEN, 2004). Major universities in Mongolia established BA and MA programs to prepare English teachers. Yet still today Mongolia remains in need of qualified English teachers, particularly in the remote rural areas.

According to the Millennium Development Goals-based Comprehensive National Development Strategy of Mongolia: 2007-2021 (GOVERNMENT OF MONGOLIA, 2008), another significant document which have emphasised English learning and teaching in Mongolia, English will be the first foreign language in Mongolia by 2015 and officials in the Mongolian public sector will be able to conduct their work in English by 2021. The ultimate goal of this comprehensive strategy is to facilitate the transition of Mongolia to a knowledge-based economy during the period 2016-2021.

In addition to the policies that have positioned English favourably in Mongolia, the forces of globalisation and the increasing use of the internet have facilitated the language's popularity amongst Mongolians. This is not unique to Mongolia as globalisation necessitates access to English as the global or international language in today's world (PENNYCOOK, 2007). English is established in Mongolia "as a prestige international language bearer of modernity" (BILLÉ, 2010, p. 243). 
Another factor contributing to the current status of English in Mongolia is the rise in the use of the internet in people's everyday lives as English still dominates the internet (INTERNET WORLD STATISTICS, 2015a), not only in terms of the content but also in terms of intercultural communication. The internet was introduced into Mongolia in 1996 (BAASANJAV, 2006). Since then the number of internet users has dramatically increased: there were 30,000 users in 2000 which increased to $1,300,000$ in 2015 (INTERNET WORLD STATISTICS, 2015b). The government of Mongolia also gives priority to use of digital technologies, evidenced by the E-Mongolia National Programme: 2005-2012 (GOVERNMENT OF MONGOLIA, 2005). In this programme, the plan was to ensure the extensive application of digital technologies in all sectors in Mongolia to lay the foundation for the knowledge-based society.

These changes in policy together with changes in the social, economic, technological and political conditions in Mongolia since 1990 have made English and digital literacies the literacies for the future of the country and its people. Thus, this paper attempts to examine the interplay between these literacies in everyday digital literacy practices of Mongolian university students majoring in English and the factors which influence those practices.

This paper is drawn on the theoretical perspectives intrinsic to Literacy Studies, particularly to digital strand of the field, that analyse digital literacy practices within the social and cultural contexts in which they occur.

\section{DIGITAL STRAND OF LITERACY STUDIES}

A Literacy Studies perspective provided a framework within which to analyse the data generated in the study reported in this paper. Instead of viewing literacy as individually acquired cognitive skills to encode and decode texts, the field of Literacy Studies approaches literacy as multiple and as a part of everyday social and cultural practices. This means that literacy is best studied in the particular contexts of social practices, such as school, work, home and community.

Associated with the proliferation of digital technologies such as computers, mobile phones, tablets and the internet, the process of globalisation, which has made the world 'smaller' than ever, and rapid socio-economic changes, literacy practices have been changing. New literacy practices are emerging and there has been a growing recognition that 'the global' needs to be recognised in Literacy Studies. The number of people who use digital technologies and social networking 
in their everyday lives is increasing rapidly worldwide with those technologies domesticated "as comfortable, useful tools - functional and/or symbolic - that are reliable and trustworthy" (BERKER, HARTMANN, PUNIE \& WARD, 2006, p. 3 ). Technologies have also been used in the field of literacy education bringing both challenges and effectiveness for teachers and students (ANDREWS, 2004). Therefore, reframing of literacy research has become necessary to understand these new contexts and the related new literacy practices.

Since the mid-1990s, studies around literacy and technology have intensified in light of the popularisation of the internet (BULFIN, 2009). Extending Literacy Studies theoretically and methodologically, a number of studies have been undertaken in the field of digital literacy studies, that have examined a variety of digital literacy practices which are "culturally and socially shaped ways of using, producing and understanding information in multiple formats from a range of sources when it is presented via the electronic screens of digital technologies" (SNYDER, 2009, p. 143). The studies have examined the digital literacy practices of people in different contexts and the educational, social, cultural and other implications of the practices for those people, their learning and teaching. For example, just to name a few in the context of digital literacy practices in using the internet during the last decade, Alvermann et al. (2012), Barton and Lee (2012), Buck (2012), Bulfin and North (2007), Carrington and Robinson (2009), Lam (2008), Lankshear and Knobel (2011), McGinnis, Goodstein-Stolzenberg and Saliani (2007), McLean (2010) and Pahl and Rowsell (2006).

Some researchers have identified frameworks to study literacy and technology from critical perspectives. For example, Warschauer (2009) and Warschauer and Ware (2008) identify three frameworks to examine literacy and technology in digital literacy studies. First, they describe a learning framework which emphasises the use of technology to enhance learning outcomes. Within this framework, technology is seen as educational as it facilitates learning in a digital environment. Second, from a change framework, the concept of literacy is transformed as it becomes associated with the emergence of new technologies. Third, a power framework, an ideological model of digital literacy, focuses on the relationship between digital literacy practices and their implications for people in gaining social, economic, and educational power (different types of capital in Bourdieusian terms). These three frameworks are intertwined: "A power framework can consider learning and change not as abstract ends but rather in the context of working to expand students' broader educational, social, and economic opportunities" (WARSCHAUER \& WARE, 2008, p. 234). These frameworks, particularly the power framework, were useful for the present 
study to examine digital literacy practices from critical perspectives, to explore the implications of the practices for the students, to understand the different values associated with digital literacy practices, and to uncover any underlying unequal access to resources which are the main factors responsible for digital inequality among students.

Overall, within the field of digital literacy studies, researchers have examined various practices with digital technologies by people of different ages, gender, social background and nationalities, in different contexts. However, there is still only a small number of qualitative studies examining the everyday digital literacy practices of university or college age students as compared with the number of studies of school children and adolescents, despite the fact that digital literacies are included as part of academic literacies in higher education.

To take account of the interplay between digital technologies, particularly the internet, and English in the age of globalisation, the next section presents briefly some perspectives about the relationships between English, the internet and globalisation which are pertinent to the present study.

\section{ENGLISH LANGUAGE, THE INTERNET AND GLOBALIZATION}

The process of globalisation is defined in many different ways from a variety of theoretical and research perspectives and disciplines. Appadurai (1996) argues that globalisation is characterised by global flows of ideas, practices, technology, money, risks, images and people. For example, students are moving to learn English which is rapidly permeating the use of digital technologies and much money is made through English learning services and products. Even though there are many definitions of globalisation, the common concepts behind many of them are "a compression of time and space, an intensification of social, economic, cultural, and political relations, a series of global linkages that render events in one location of potential and immediate importance in other, quite distant locations" (PENNYCOOK, 2007, p. 25).

Although there are benefits of the globalisation process in relation to the compression of space and time, disparities still exist between those included and those excluded from the powerful networks (CASTELLS, 2000). As globalisation and the internet have strengthened the trend of English becoming the dominant language of international business, entertainment, and scholarship, those who speak 
English are privileged over those who do not (WARSCHAUER, 1999). Thus, English also plays inclusionary and exclusionary roles in society.

Even though the dominance of English on the internet is homogenising language use in digital environments by threatening other languages and cultures, this process leads to 'glocalisation' which "entails a synergetic relationship between the global and the local as opposed to the dominance of the former over the latter and the homogenisation which would result from such dominance" (BLOCK, 2012, p. 60). This concept is defined by Koutsogiannis and Mitsikopoulou (2007) in their study of online language use in Greece as "a dynamic negotiation between the global and the local, with the local appropriating elements of the global that it finds useful, at the same time employing strategies to retain its identity" (p. 143). Clearly, the relationship between the global and the local is a mutual process, with each affecting the other.

There is a manifestation of the interface between English and the internet not only in the relationship between the global and the local in the digital environment but also in people's endeavours to learn the language using the internet in the age of globalisation. Young people today are learning and practising their English language informally through a variety of online practices (BLACK, 2009; LAM, 2008; McLEAN, 2010). For example, Black (2009) discusses three adolescents' participation in online fan fiction communities, in which they develop their English writing skills through writing and commenting on each other's writing. Like other researchers, Black suggests that teachers draw on their students' non-academic digital literacy practices to make language education more authentic reflecting not only students' needs and experiences outside of the classrooms but also local and global changes.

Just as the internet can facilitate learning English, both English and the internet are also vital resources for learning when learning is viewed as a socially situated phenomenon (ROGOFF, 1994; WENGER, 1998). Drawing on a social learning perspective, Barton and Lee (2013) describe how people learn online. They argue that people learn by participating in practices on the internet that draw on others as resources for learning and by being reflexive about their future goals and circumstances: importantly, their identities are changed as a result of such learning. As Lankshear and Knobel (2011) suggest, the internet can be used as a platform for collaborative learning in educational settings. Learning is situated in social practices on the internet; because of the internet, the borders between everyday informal learning and formal learning in educational contexts are becoming indistinct. 
With these issues in mind, this paper aims to examine the realities of digital technology use of university students from Mongolia and discuss what factors and benefits are associated with their technology use.

\section{THE STUDY}

As quantitative studies generally yield little detailed information, different methodologies are required to undertake a contextual analysis of students' digital literacy practices. The present study used a mix of methods but with the qualitative predominating: a survey completed by 98 students to obtain general information about the students' uses of digital technologies and English, and to provide a broad context for the in-depth case studies, and detailed case studies of six students. As the research aimed to garner a deep understanding of the students' literacy practices with digital technologies, especially the internet, within the specific social contexts of their lives and experiences, a case study approach was adopted. An advantage of a case study approach in Literacy Studies is that by examining a small number of cases and focusing on various data sources, researchers can contextualise the experiences of individuals and understand the ways participants make sense of those experiences (COMPTON-LILLY, 2007). Furthermore, a reason for using mixed methods was to enhance the quality of the research by making possible the triangulation of data sources and to gain multiple perspectives from different types of data. The study applied both quantitative (survey) and qualitative (interviews, observations, techno-biographies) components concurrently.

The survey was useful to gain information from 98 students in a relatively short period of time to "develop an overall picture" (BARTON, 2007, p. 54) of the students' uses of English and digital technologies and their perceptions of them. Interviews in this study provided insight into the participants' identities including their values, attitudes, beliefs and aspirations, as well as into the popular discourses around English and online practices in Mongolia. An observation was conducted during the second individual interview with participants for about an hour asking them to use a laptop computer connected to the internet in a way that they described as typical uses for them. The case study participants were also requested to write their technological biographies or techno-biographies as narratives to gain an in-depth understanding of their past and present experiences and practices with digital technologies in the context of their life stories. 
The study was carried out in a public university in Ulaanbaatar, which is the only major and cosmopolitan city in Mongolia where nearly half of the total population lives. The third and fourth year undergraduate students majoring in English language were invited to participate in the study on a voluntary basis. The reason for this choice of year level was that these students had studied English for three or four years and were likely to be more familiar and experienced with the use of English and digital technologies in their everyday practices than first and second year students. The survey respondents' mean age was $21(\mathrm{SD}=2.16)$. Forty-three of them were from urban areas including the capital city, Ulaanbaatar, and two other cities, Darkhan and Erdenet. The gender ratio - 9 male and 89 female - reflects the general gender ratio in Mongolian universities which emerged after the 1990 transition from socialism to a market economy. The case study participants included five females and one male student. All were in their final year of university when the data were collected. Pseudonyms were used to protect the identity of the participants in this research because of the ethical concerns. The six case study participants' profiles are presented below in the Table 1 to provide their backgrounds.

Table 1. Case study participant profiles

\begin{tabular}{|c|c|c|c|c|c|c|}
\hline Name & Bat & Alimaa & Naraa & Saraa & Ariun & Nomin \\
\hline Gender & Male & Female & Female & Female & Female & Female \\
\hline Age & 23 & 22 & 21 & 22 & 22 & 22 \\
\hline $\begin{array}{l}\text { Origin (urban/ } \\
\text { suburban/ } \\
\text { rural) }\end{array}$ & Rural & Urban & Suburban & Suburban & Rural & Rural \\
\hline Family attributes & $\begin{array}{l}\text { Mother: } \\
\text { U n e m - } \\
\text { p lo y e d } \\
\text { (Seconda- } \\
\text { ry school } \\
\text { English te- } \\
\text { acher) } \\
\text { Siblings: } \\
\text { None }\end{array}$ & $\begin{array}{l}\text { Fathe r: } \\
\text { Pianist; } \\
\text { D i r e c - } \\
\text { tor of an } \\
\text { NGO } \\
\text { Mother: } \\
\text { Computer } \\
\text { engineer; } \\
\text { Journalist } \\
\text { Siblings: } \\
\text { None }\end{array}$ & $\begin{array}{l}\text { Fathe } \mathrm{r} \text { : } \\
\text { Merchant } \\
\text { (Aviation } \\
\text { technician) } \\
\text { Mother: } \\
\text { Primary } \\
\text { school te- } \\
\text { acher } \\
\text { Siblings: } \\
\text { Two youn- } \\
\text { ger bro- } \\
\text { thers and } \\
\text { a younger } \\
\text { sister }\end{array}$ & $\begin{array}{l}\text { Mother: } \\
\text { Doctor at } \\
\text { a district } \\
\text { hospital } \\
\text { Siblings: } \\
\text { An older } \\
\text { sister and } \\
\text { a younger } \\
\text { brother }\end{array}$ & $\begin{array}{l}\text { Father: } \\
\text { Merchant } \\
\text { (Driver) } \\
\text { Mother: } \\
\text { Merchant } \\
\text { ( L a n d } \\
\text { manager) } \\
\text { Siblings: } \\
\text { Two older } \\
\text { brothers }\end{array}$ & $\begin{array}{l}\text { Father: } \\
\text { Governor } \\
\text { of 'Bag' and } \\
\text { herdsman } \\
\text { Mother: } \\
\text { Herdswo- } \\
\text { man } \\
\text { Siblings: } \\
\text { Two youn- } \\
\text { ger bro- } \\
\text { thers }\end{array}$ \\
\hline
\end{tabular}




\begin{tabular}{|c|c|c|c|c|c|c|}
\hline $\begin{array}{l}\text { Residential loca- } \\
\text { tion }\end{array}$ & $\begin{array}{l}\text { Public apt } \\
\text { in a suburb }\end{array}$ & $\begin{array}{l}\text { Apt in the } \\
\text { city }\end{array}$ & $\begin{array}{l}\text { S t ud e n t } \\
\text { dormitory }\end{array}$ & $\begin{array}{l}\text { House in } \\
\text { a ger dis- } \\
\text { trict }\end{array}$ & $\begin{array}{l}\text { S t u d e n t } \\
\text { dormitory }\end{array}$ & $\begin{array}{l}\mathrm{Stude} \mathrm{nt} \\
\text { dormitory }\end{array}$ \\
\hline $\begin{array}{l}\text { Type of internet } \\
\text { access }\end{array}$ & $\begin{array}{l}30 \text { minutes } \\
\text { free inter- } \\
\text { net access } \\
\text { at Ameri- } \\
\text { can Edu- } \\
\text { cational } \\
\text { Centre }\end{array}$ & $\begin{array}{l}\text { Cable in- } \\
\text { ternet at } \\
\text { home }\end{array}$ & $\begin{array}{l}\text { Internet } \\
\text { cafés and } \\
\text { at uni lab } \\
\text { (rarely) }\end{array}$ & $\begin{array}{l}\text { Cable in- } \\
\text { ternet at } \\
\text { home }\end{array}$ & $\begin{array}{l}\text { Free wi- } \\
\text { reless at a } \\
\text { dormitory }\end{array}$ & $\begin{array}{l}\text { Free wi- } \\
\text { reless at a } \\
\text { dormitory }\end{array}$ \\
\hline $\begin{array}{l}\text { Computer } \\
\text { ownership }\end{array}$ & Laptop & Desktop & $\begin{array}{l}\text { Desktop at } \\
\text { home }\end{array}$ & $\begin{array}{l}\text { Desktop; } \\
\text { Laptop }\end{array}$ & Laptop & Laptop \\
\hline $\begin{array}{l}\text { Other technolo- } \\
\text { gies owned }\end{array}$ & $\begin{array}{l}\text { Mo b i l e } \\
\text { p h o n e, } \\
\text { digital ca- } \\
\text { mera }\end{array}$ & $\begin{array}{l}\text { M o b i - } \\
\text { le pho- } \\
\text { ne, MP4 } \\
\text { p l a y e r, } \\
\text { digital ca- } \\
\text { mera }\end{array}$ & $\begin{array}{l}\text { Mo b i } 1 \text { e } \\
\text { phone }\end{array}$ & $\begin{array}{l}\text { Mobile } \\
\text { p ho n e, } \\
\text { iPod, MP4 } \\
\text { player. }\end{array}$ & $\begin{array}{l}M \text { o b i - } \\
\text { le pho- } \\
\text { ne, } \quad \text { MP3 } \\
\text { player }\end{array}$ & $\begin{array}{l}\text { M o b i l e } \\
\text { p h o n e, } \\
\text { MP4 player }\end{array}$ \\
\hline
\end{tabular}

The participants were from different family and educational backgrounds. There was considerable differentiation amongst them in their living conditions, socioeconomic status and internet access. This diversity helped me to explain digital inequality amongst them and to look at the digital literacy practices of students from different backgrounds and their perspectives on their practices.

The survey data were analysed using both quantitative and qualitative techniques since some questions were closed and some open-ended. SPSS (version 20) software was used to analyse the quantitative items to produce a set of descriptive statistics, that is, reporting the responses to items on the survey through cross-tabulation, means and standard deviation to look for relationships between the responses and the students' characteristics. Recurrent categories or themes were discovered among the responses to each open-ended question and were sorted. Employing 'open' coding, the views of all participants were examined and analysed in light of the theories and methods that have been discussed earlier. Compiling detailed portraits of the case study participants proved to be really useful as a way to begin to synthesise the information and to check particular themes or patterns related to their digital literacy practices across all the participants. A matrix, with cases in the columns and concepts or categories in the rows (BARTON \& HAMILTON, 1998) helped me to sort the information about the category and to gain in-depth understanding about each case. 


\section{RESULTS}

\section{The survey}

English and digital literacies were linked inseparably in the data because they were mutually beneficial and interdependent and both were resources for the students for their living and learning. For example, the most popular use of English amongst the students ( $80 \%$ of the respondents) was related to using the internet, whereas the most popular use of digital technologies was related to learning English. This shows that English was a tool to access the internet which helped students to be informed, to entertain themselves, to communicate with their friends and online communities, and to practise or improve their English skills. However, there was an urban-rural divide in accessing the internet. Figure 1 shows this divide.

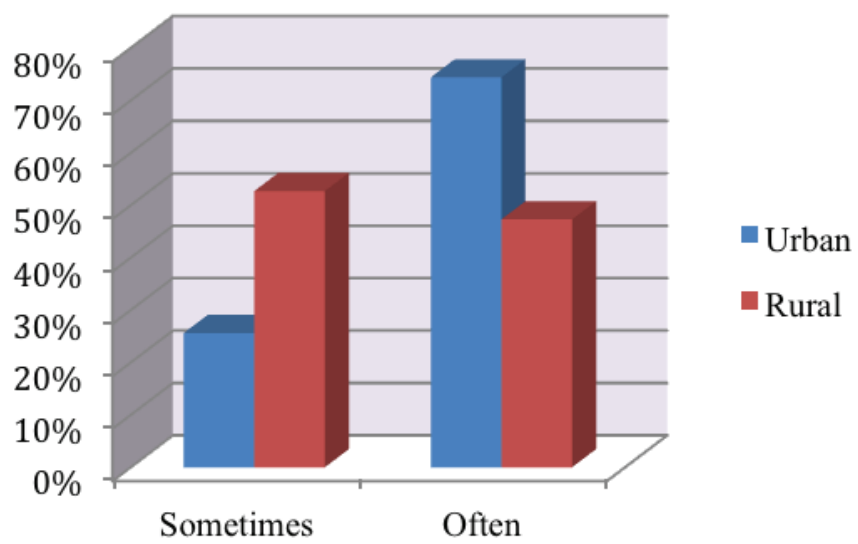

Figure 1. Frequency of accessing the internet

It is evident that there was a discernible difference between the students' internet access levels based on their origins, urban or rural. This online divide can be explained by many factors, such as students' English proficiency, digital literacies and socio-economic status. For example, every student from rural areas cannot stay in dormitories in Ulaanbaatar where free wireless internet was available, as the dormitories have limited space. Mostly, depending on their economic capital, the students from rural areas stayed at their relatives' places or 
shared rented gers ${ }^{1}$ or apartments. Some of them could have been living in places where an internet connection was available but some did not. Some could afford an internet connection whereas some could not. The students' socio-economic status really influenced their internet use in the field of higher education in Mongolia.

Some students in this study could have felt excluded depending on their English proficiency. For example, 21\% of the total students stressed that they used English "only during English classes at university". They said that it was hard for them to use English in other contexts since nobody around them spoke English and there was no environment for them to use their English. Those students were mostly from the rural areas. It seems students from urban areas have more access to English and have more opportunities to practise the language through their social networks which enhanced their English proficiency. Because of the unequal distribution of 'resources', in rural and urban areas in Mongolia urban students are more advantaged in learning English and using the internet.

The next most common use of English, after on the internet, was related to media consumption: watching TV and reading newspapers. The students watched the news, TV shows and a lot of other programmes in English on cable TV and read the two weekly newspapers in English. There are numerous channels in English in Mongolia for cable TV subscribers which can be good resources for English learners. The next common use was related to entertainment or recreational activities. Students listened to online music and songs, watched video clips on YouTube and downloaded songs or movies from the internet using English. The students used English to keep themselves informed and entertained, at the same time as they practised and improved their English skills. This means that learning and entertainment were closely related for the students when they used the internet.

Though there was an urban-rural divide in the respondents' internet access there was not a student who did not access the internet among them. They all had a computer, either a laptop or a desktop or both, except five students from rural areas. Among the students who had computers, there were not big differences in terms of the urban and rural disparity. For instance, $50 \%$ of the respondents (22 urban and 27 rural) had their own laptops while 73\% (34 urban and 38 rural) had desktop computers. Even the average hours that the students spent using these digital technologies were quite close between the urban and rural students. Most respondents spent up to five hours daily using their laptops and desktop computers.

\footnotetext{
${ }^{1}$ Traditional dwelling in Mongolia, which is a portable round-shaped felt tent, used by the nomads for centuries. Many Mongolians still live in ger districts that have no plumbing and do not meet sanitary requirements, having to buy drinking water from local water stations.
} 
Fifty-two percent of the students (23 urban and 28 rural) spent up to five hours each day using their desktop computers, while $39 \%$ of them (15 urban and 23 rural) spent the same amount of time using their laptops.

Communication took high priority among the students and friendship-driven activities, emailing and chatting online, dominated in their everyday digital literacy practices. The least popular activities were online shopping and writing blogs. This could have been associated with the unpopularity of online shopping in Mongolia and students' digital literacy levels. Overall, communication, getting information and entertainment took high priority in the respondents' online activities. The students were not engaged much with content creation activities, such as blogging.

Figure 2 shows further analysis to see whether the survey respondents' origins, rural or urban, impacted on their language choices when they used the internet.

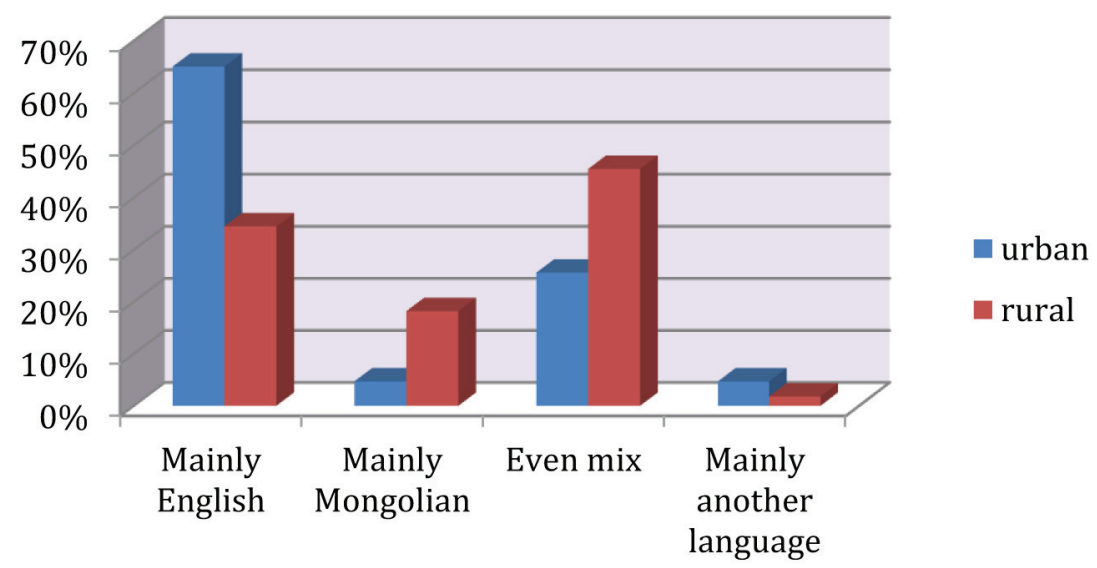

Figure 2. Survey respondents' origins and online language uses

The graph shows that students from urban areas mostly used English in their online activities, whereas students from rural areas mostly used Mongolian or they mixed English and Mongolian. A very small percentage of the students used another language on the internet. The data clearly show that there was an urbanrural divide in relation to the uses of English and the internet. Further, this divide could have impacted on their academic study as English continues to dominate the internet and the students who used mainly English must have located much more information and knowledge in their study areas, which was English. 
When students explained their language choices on the internet, the most frequently mentioned reasons among those who used mainly English were that: "English prevails on the internet"; "I wish to improve my English"; and "almost every website I use is in English". Interestingly, two students said that using English was just a habit for them since everyone was using the language. Another three students reasoned that English was their second language and it was easier than using Mongolian. Two students said that "English sources are more reliable than Mongolian ones". All these statements show how English dominates the internet, how English and the internet are interwoven and how much the students preferred English to Mongolian.

Most of the students who used both English and Mongolian online reasoned that Mongolian was used for reading the news on Mongolian websites and communicating with their friends, while English was used for getting the world news, studying at university and entertaining themselves. Three students commented that they mixed both languages when they chatted and texted. This practice of codemixing or codeswitching has become a norm in chatting and texting among Mongolian youth.

Most of the students who used mainly Mongolian on the internet related their choice to their English proficiency. No other reasons were mentioned except by one student who said: "I do not have much access to the internet so it is quicker to read in Mongolian than in English". But even her answer implied that her choice was also related to her English proficiency. Only three students used another language on the internet: two were from urban areas and one from a rural area. In terms of language diversity, the survey respondents were not so diverse in their practices.

Students' perceptions of the significance of English and digital literacy practices in their future careers and lives were quite similar. Forty-nine percent of the students assumed that English and digital literacy practices would help them to get a good job and $31 \%$ said that their future would depend on those literacies and that they were the essentials of their lives. The next popular perceptions among the respondents were that English and digital literacies would help them to gain knowledge and information, to study further, to be educated, and to communicate with the 'world' and make friends. Both English and digital literacies were prioritised and had high status attributed to them by the students as resources or cultural capital for their future lives and as powerful literacies in the $21^{\text {st }}$ century. In short, most students perceived English and digital literacies as powerful resources for their future. 
The survey revealed that the use of English was inseparable from the students' digital literacy practices even though they had different levels of proficiency in English and used Mongolian when they read local websites for news and entertainment.

\section{The case study}

All the case study participants believed that both English and digital literacies would ensure a future career, studying abroad, getting information easily and quickly, learning and providing ways to spend their leisure time. Naraa, who was a frank, ambitious and hardworking student and whose English was good but not fluent, believed that English and computer literacy would help her to develop and earn money, and that eventually the two combined would lead to a happy life. Saraa, who was a smart, self-confident, very busy student and whose English was fluent, could not imagine life without English and the internet since they enabled her to keep up-to-date and to plan her future. Likewise, Alimaa, who was an artistic, communicative, open minded and cheerful student and whose English was fluent, could not imagine herself without English and the internet since all her work and friendships were linked through them. Bat, who was a modest and patriotic young man and whose English was fluent, asserted that English was helpful if combined with digital literacies. For Nomin and Ariun, who had not studied English before they became students, the internet was a tool to improve their English. Thus, the case study participants believed that English and digital technologies were valuable resources for them to access the sources of income in the labour market reflecting the predominant concern amongst survey respondents in the study: they represented forms of power or capital.

Illuminating the inseparability of English and the internet as found in the survey data, in the individual interviews, the participants talked specifically about how English and the internet were linked in their everyday practices. First, the fact that English dominated on the internet predisposed them to use English when online:

There are not enough websites in Mongolian on which I can get information that I need. I use English to get information as the most interesting information is in that language.

Extract 1 (Naraa - interview 1) 
I use Mongolian for online chatting and texting via my mobile phone while English is used to get information on the internet.

Extract 2 (Ariun - interview 1)

I can use the internet with the assistance of English to get up-to-date information. I mostly use English on the internet as I access the websites in English. Sometimes I think that for the people who do not know English it would be really hard to use the internet. Also, to get information from the original sources we need to use English.

Extract 3 (Saraa - interview 1)

The participants gained an advantage on the internet: to go beyond the local by getting information, support and advice in English, a global language. Though the dominance of English on the internet limits some people's access to it, on the other hand, it represents an important resource for students who are learning the language.

Second, by using the internet the participants practised and learnt English. Thus, English and the internet had a symbiotic relationship:

Thanks to the internet my writing skill improved because every time I write, from leaving a comment for a photo to writing an email, I have to think what to write and how to express myself in the right way in English. Eventually, this could bring ideas for future essays.

Extract 4 (Bat - interview 2)

Bat implied that there was a direct relationship between his use of the internet in his everyday digital literacy practices and the improvement of his English. Similarly, Alimaa attributed her academic achievements to her internet use via English:

Though I am not spending enough time on my study as I work, I am surprised that I get higher scores than the students who studied hard. But the fact that I use the internet a lot through my English has impacted on improving my English skills. Those students have limited access to the internet. Importantly, reading a variety of information in English and downloading it helped me to learn more about sentence structures in English and to develop my vocabulary. In other words, I do not rely only on the textbooks but also on different points of view on the internet.

Extract 5 (Alimaa - interview 2) 
The internet was a vital resource for these participants to support their study and learn English. The fact that Alimaa got higher scores than other students who studied hard with limited access to the internet showed how the internet was a resource for informal learning. Another participant, Nomin, also asserted the importance of learning English through an informal channel, that is, the internet:

If we study at university by just doing our homework, our English will not improve much. After getting a laptop last year, I started to try to improve my English beyond university courses by using the internet and this paid off. My English got much better. Extract 6 (Nomin - interview 1)

The internet played a significant role in improving English for these participants and they took advantage of it through the added value of 'English + internet'.

Third, English and computer literacy were both considered to be useful for the participants' future lives as they always went together and were commonly associated in Mongolian society: they were intrinsic to most job requirements and indicated people's education level. They were "just the requirements for every young person" (Alimaa - interview 1). They had already been localised in Mongolia as the literacies which should be developed in the $21^{\text {st }}$ century, in the age of globalisation. Further, in the individual interviews the students expressed their views on what it means to be an educated person in Mongolian society in very similar ways. For them, any educated person needed to be literate in English and proficient with computers and the internet, to meet their work and study demands. In these ways, all of them valued English and digital literacies as important markers of an educated person, as did more than 20 survey respondents.

Plus, the case study participants' aspirations were embodied in their digital literacy practices. They aspired towards their future careers and to study abroad which would eventually facilitate their upward social mobility. In preparation, they all managed and negotiated their time to engage in aspiration-driven practices on the internet. They always tried to improve their English through their practices which was an instantiation of their dispositions towards self-development or self-improvement because of their shared belief that English and digital literacies would help them to get jobs and to study abroad.

Based on my English proficiency I want to study for a Master's degree in a different major. I want to study abroad if I can get a scholarship.

Extract 7 (Naraa - interview 1) 
My future career will heavily depend on my English proficiency and computer literacy. Frankly speaking, without these, there is no future career for me.

Extract 8 (Nomin - interview 1)

I want to do my Master's degree in environmental studies. I have just found out on the internet that the best education in this research area is delivered in Norway. So the internet helps me to get useful information like this and to plan my future.

Extract 9 (Saraa - interview 1)

I will develop myself through learning English and about computers more. Then, it will be easier for me to work in the future and communicate with people.

Extract 10 (Bat - interview 1)

Getting a job after graduation was the immediate aspiration for the case study participants as they were to graduate soon after the data collection ended. In addition, the social contexts in which they were located and particular circumstances shaped their aspirations. For example, Naraa said that she wanted to get a job as soon as she graduated to rent an apartment, sharing with other people, as she did not want to stay with her family in a small house in a ger district (interview 2). She was, in fact, ashamed of living in a ger district and did not tell the other students. She wanted to distance herself from the ger district by living in an apartment which is a marker of social status. Using her English language skills and the internet she was earning a living and moving toward her ultimate goal which was to become a successful woman. Bat also wanted to get a job immediately after his graduation, which is why he had put his CV on LinkedIn. He also said that he would get an internet connection at home when he got a job (interview 2).

For the case study participants, it was also difficult to separate their use of English from their computer and internet use. As they were all engaged with digital literacy practices, thanks to their English, the internet helped them to learn and improve their English, that is, they were mutually reinforcing, as found in the survey.

\section{DISCUSSION}

The findings from both the survey and the case study data showed that the students used computers and the internet in their everyday lives to keep abreast of current local and global events, to communicate, to establish and maintain their social networks, to complete their assignments and to entertain themselves. In this 
study, the students' internet uses for all these purposes were intimately related to learning, especially improving English and acquiring digital literacies. Learning was the main priority for the participants' engagement in online practices. For most of the 104 participants in this study, English and digital literacies were the literacies of power (JANKS, 2010; WARSCHAUER, 2003) in an age of globalisation. They valued and wanted to gain access these literacies through investing their time and labour and by being strategic and agentive in their everyday digital literacy practices to reach their ultimate goal of getting jobs and studying abroad. This shows how not only English but also digital literacy practices "come to the forefront as the means through which workplace competence is judged" (HELLER, 2008, p. 59). In addition, most students had similar aspirations for studying abroad as aspirations are "always formed in interaction and in the thick of social life" (APPADURAI, 2004, p. 67). This relates to the reality in Mongolia that degrees from universities abroad are more prestigious than those from local universities: they enhance people's career opportunities and designate their social status.

In terms of access and activities, the results in the present study were not so different from some studies of university students' internet use in Australia and the UK which were based on surveys investigating the extent to which digital technologies were integrated in their studies and their use of technology in their everyday lives (HENDERSON et al., 2015; KENNEDY et al., 2008; SELWYN, 2008) as most of the student respondents used mobile phones, computers and the internet in their everyday lives to do their assignments, learning, searching for information, communication and leisure, though the hours of use varied. The findings in this and the above-mentioned studies indicate that students have different levels of access to technologies depending on their socio-economic status, engage in different online activities and have different skills. For instance, content and knowledge creation activities with Web 2.0 were undertaken infrequently by the students in this and in the study conducted by Kennedy et al. (2008) with the exception of social networking. It can be concluded that the use of technology in the students' everyday lives is not as ubiquitous as might be expected.

In fact, the proliferation of digital technologies has created an assumption that university students as young and well-educated individuals use the internet as a source of information in their everyday lives for a range of purposes including for academic purposes (SELWYN, 2008). This population, however, consists of individuals from different backgrounds and with different levels of resources in using technologies and the universities they are attending are also diverse in terms of their facilities and resources for students. The current study shows that it is 
not possible to generalise about their technology use as there are many underlying factors that influence how they use the technologies, from their socio-economic status to their dispositions towards the technologies. In this study, for example, the impact of the binary - urban vs. rural - on the students' digital literacy practices and proficiency with English was evident among both the survey and the case study participants. According to the survey findings, the students from urban areas used the internet frequently and in the main used English in their online activities. This divide also existed amongst the case study participants. Living in suburban ger districts in Ulaanbaatar influenced whether they had an internet connection at home, as in some districts the internet was not available. As seen in Alimaa's case, her family's socio-economic status and living near the city centre had enabled her to have internet access for quite a few years, whereas Naraa, who lived in a suburban ger district where the internet was not available, relied on internet cafés until she leased a laptop just before her graduation.

Structural constraints such as the geographical location of the places where the students lived influenced not only their access to the internet but also their access to English, one of the main resources with which to engage with the internet. Because of the unequal distribution of resources in urban, suburban and rural areas in Mongolia, urban students were more advantaged in learning English. Though English has been a regular school subject in Mongolia for over two decades, the schools in rural areas still lack qualified English teachers because most graduates from universities prefer to live in the cities. Because of their remoteness, most rural areas have limited resources for learning English, including access to the internet. Thus, the resources that the participants used to access digital technologies, such as English proficiency, shaped their practices.

The study also shows that mixing and codeswitching English and Mongolian has become popular for young Mongolians. According to Dovchin (2011), the language of popular music in Mongolia is the major site to mix and codeswitch English and Mongolian for young Mongolians, as English is the main language for naming music bands and artists, songs and concerts, and English phrases are used in lyrics. Further, she claims that 'Youth Monglish' (the mixture of English and Mongolian) is popular amongst the urban youth in Mongolia after examining the message board under a music video by a Mongolian singer on the internet. Through popular cultures, nowadays, young people mix English with their native languages and enforce the global linguistic flow of English.

However, the current status of English in Mongolia led some scholars and people to be more nationalistic and supportive of their native language and 
to challenge the widely perceived superiority of English. For instance, Lodon (2009) has made an appeal for the defence of the Mongolian language in response to the plan in the Mongolian Millennium Challenge Goals (GOVERNMENT OF MONGOLIA, 2008). He argues that English is 'violating' the Mongolian language making it a 'broken' language and suggests ways to defend the Mongolian language, such as creating more Mongolian websites, not using English words in the media, stopping the implementation of a plan which aims to make officials in the Mongolian public service sector conduct their work in English by 2021 as outlined in the document. In this sense, English should be taken as an additional language to native languages in light of Koutsogiannis and Mitsikopoulou (2007)'s definition of glocalisation. The dominance of English may have raised people's awareness of their native language which is one of the advantages of the global spread of English (PENNYCOOK, 2007) as language becomes critical in the defence of local identity (WARSCHAUER, 2002).

\section{CONCLUSION}

This paper focuses on how English and the internet were linked in Mongolian university students' everyday practices and how they were valued by the university students as resources to support their personal development and to assist them in achieving their future goals. The survey results of 98 students provided a broad context and base for the discussion of the case study data. In the study, English and digital literacies are brought together as resources which young Mongolians need to access, not only to gain employment but also to develop themselves personally and to establish networks locally and globally. The study also revealed that there were digital and linguistic distinctions amongst the students due to their family and educational backgrounds. On the whole, the students' literacy practices were implicated in their endeavours to become fluent in English which was related not only to their major at university but also to their aspiration to get good jobs, study abroad and eventually raise their social status.

The study found that the inequalities amongst the students were directly related to their access to English and digital technologies prior to becoming students. The inequalities associated with students' previous schooling can be ameliorated, in part, through the provision of quality English and digital literacies education for children from all social backgrounds. They require opportunities to develop these vital literacies for their personal benefit and for academic learning in 
the context of the global knowledge economy. To ensure that this occurs, it is time for teachers to rethink how the subjects associated with developing such literacies are taught.

In the main, English and the internet have become global phenomena and forces of globalisation. They are the means of spreading and exchanging information globally. They are on the one hand opening people's lives to diversity but on the other hand constraining how this diversity can be accessed and expressed. However, through appropriating English and the internet for their own needs, people can be exposed to many opportunities including learning.

\section{REFERENCES}

ALVERMANN, D. E., MARSHALL, J. D., McLEAN, C. A., HUDDLESTON, A. P., JOAQUIN, J., \& BISHOP, J. (2012). Adolescents' web-based literacies, identity construction, and skill development. Literacy Research and Instruction. v. 51, $\mathrm{n}^{\circ} 3$, pp: 179-195.

ANDREWS, R. (Ed.). (2004). The impact of ICT on literacy education. London \& New York: Routledge Falmer.

APPADURAI, A. (1996). Modernity at large: Cultural dimensions of globalization. Minneapolis: University of Minnesota Press.

APPADURAI, A. (2004). The capacity to aspire: Culture and the terms of recognition. In: V. Rao \& M. Walton (Eds.), Culture and public action. California: Stanford University Press, pp: 59-84.

BAASANJAV, U. (2006). Internet content and use by civil society and governmental institutions in Mongolia: The situation in 2005. Doctoral dissertation. Ohio University, USA.

BARTON, D. (2007). Literacy: An introduction to the ecology of written language. Malden, MA: Blackwell Publishing.

BARTON, D., \& HAMILTON, M. (1998). Local literacies: Reading and writing in one community. London \& New York: Routledge.

BARTON, D., \& LEE, C. (2012). Redefining vernacular literacies in the age of Web 2.0. Applied Linguistics. v. 33, $\mathrm{n}^{\circ} 3$, pp: 282-298.

BARTON, D., \& LEE, C. (2013). Language online: Investigating digital texts and practices. London \& New York: Routledge.

BERKER, T., HARTMANN, M., PUNIE, Y., \& WARD, K. J. (2006). Introduction. In: T. Berker, M. Hartmann, Y. Punie \& K. J. Ward (Eds.), Domestication of media and technology. England: Open University Press, pp. 1-17.

BILLÉ F. (2010). Sounds and scripts of modernity: Language ideologies and practices in contemporary Mongolia. Inner Asia. v. 12, pp. 231-252. 
BLACK, R. W. (2009). English-language learners, fan communities, and 21st-century skills. Journal of Adolescent \& Adult Literacy. v. 52, nº 8, pp: 688-697.

BLOCK, D. (2012). Economising globalisation and identity in applied linguistics in neoliberal times. In: D. Block, J. Gray \& M. Holborow (Eds.), Neoliberalism and applied linguistics. UK \& USA: Routledge, pp. 56-85.

BUCK, A. (2012). Examining digital literacy practices on social network sites. Research in the Teaching of English. v. 47, n 1 , pp: 9-38.

BULFIN, S. (2009). Literacies, new technologies and young people: Negotiating the interface in secondary school. Doctoral dissertation. Monash University, Australia.

BULFIN, S., \& NORTH, S. (2007). Negotiating digital literacy practices across school and home: Case studies of young people in Australia. Language and Education. v. 21, $\mathrm{n}^{\mathrm{O}} 3$, pp: $247-263$.

CARRINGTON, V., \& ROBINSON, M. (Eds.). (2009). Digital literacies: Social learning and classroom practices. Los Angeles \& London: Sage.

CASTELLS, M. (2000). The rise of the network society (2nd ed.). Oxford, UK: Blackwell Publishers.

COHEN, R. (2004). The current status of English education in Mongolia. Asian EFL Journal. v. 6, n ${ }^{\circ}$ 4, Article 2. Available at: http://www.asian-efl-journal.com Accessed: 10 March 2008.

COMPTON-LILLY, C. (2007). The complexities of reading capital in two Puerto Rican families. Reading Research Quarterly. v. 42, nº 1, pp: 72-98.

DOVCHIN, S. (2011). Performing identity through language: The local practices of urban youth populations in post-socialist Mongolia. Inner Asia. v. 13, pp. 315-333.

FORSETH, C. \& FORSETH, R. (1996). English "isolation" in Mongolia: An English only camp. TESOL. v. 5, n ${ }^{\circ} 3$, pp. 10-13.

GOVERNMENT OF MONGOLIA. (2001). The national policy on improving the quality of English teaching. Ulaanbaatar, Mongolia.

GOVERNMENT OF MONGOLIA. (2005). E-Mongolia national programme. Ulaanbaatar, Mongolia.

GOVERNMENT OF MONGOLIA. (2008). Millennium development goals-based comprebensive national development strategy of Mongolia: 2007-2021. Ulaanbaatar, Mongolia.

GOVERNMENT OF MONGOLIA. (2010). National programme on "Education" (2010-2021). Ulaanbaatar, Mongolia.

HELLER, M. (2008). Bourdieu and "literacy education". In: J. Albright \& A. Luke (Eds.), Pierre Bourdieu and literacy education. New York \& London: Routledge, pp: 50-67.

HENDERSON, M., SELWYN, N., FINGER, G., \& ASTON, R. (2015). Students' everyday engagement with digital technology in university: Exploring patterns of use and 'usefulness'. Journal of Higher Education Policy and Management. v. 37, n 3, pp: 308-319.

INTERNET WORLD STATISTICS. (2015a). Internet world users by language. Available at: http://www.internetworldstats.com/Accessed: 15 December 2015. 
INTERNET WORLD STATISTICS. (2015b). Asia internet use, population data and Facebook statistics. Available at: http://www.internetworldstats.com/Accessed: 15 December 2015.

JANKS, H. (2010). Literacy and power. New York \& London: Routledge.

KENNEDY, G., DALGARNO, B., BENNETT, S., JUDD, T., GRAY, K., \& CHANG, R. (2008). Immigrants and natives: Investigating differences between staff and students' use of technology. Paper presented at the Hello! Where are you in the landscape of educational technology?, Melbourne, Australia. Available at: http://www.ascilite. org.au/conferences/melbourne08/procs/index.htm Accessed: 3 March 2011.

KOUTSOGIANNIS, D. (2007). A political multi-layered approach to researching children's digital literacy. Language and Education. v. 21, $\mathrm{n}^{\circ} 3$, pp: 216-231.

KOUTSOGIANNIS, D., \& MITSIKOPOULOU, B. (2007). Greeklish and greekness: Trends and discourses of "glocalness". In: B. Danet \& S. C. Herring (Eds.), The multilingual internet: Language, culture, and communication online. New York: Oxford University Press, pp. 142-160.

LAM, W. S. E. (2008). L2 literacy and the design of the self: A case study of a teenager writing on the Internet. In: J. Coiro, M. Knobel, C. Lankshear \& D. J. Leu (Eds.), Handbook of research on new literacies. New York: Lawrence Erlbaum, pp. 1189-1212.

LANKSHEAR, C., \& KNOBEL, M. (2011). New literacies: Everyday practices and social learning (3rd ed.). Maidenhead: Open University Press.

LODON, T. (2009). Language violence. Available at: www.olloo.mn Accessed: 1 April 2010.

McGINNIS, T., GOODSTEIN-STOLZENBERG, A., \& SALIANI, E. C. (2007). "indnpride": Online spaces of transnational youth as sites of creative and sophisticated literacy and identity work. Linguistics and Education. v. 18, pp: 283-304.

McLEAN, C. (2010). A space called home: An immigrant adolescent's digital literacy practices. Journal of Adolescent \& Adult Literacy. v. 54, n 1, pp: 13-22.

NATIONAL STATISTICAL OFFICE OF MONGOLIA. (2016). Population of Mongolia. Available at: http://www.en.nso.mn Accessed 20 January 2016.

PAHL, K., \& ROWSELL, J. (Eds.). (2006). Travel notes from the New Literacy Studies: Instances of practice. Clevedon: Multilingual Matters Ltd.

PENNYCOOK, A. (2007). Global Englishes and transcultural flows. London \& New York: Routledge.

PRINSLOO, M., \& ROWSELL, J. (2012). Digital literacies as placed resources in the globalised periphery. Language and Education. v. 26, n ${ }^{\circ}$ 4, pp. 271-277.

SELWYN, N. (2008). An investigation of differences in undergraduates' academic use of the internet. Active Learning in Higher Education, 9(1), 11-22.

ROGOFF, B. (1994). Developing understanding of the idea of communities of learners. Mind, Culture, and Activity. v. 1, no 4, pp: 209-229.

SNYDER, I. (2009). Shuffling towards the future: The enduring dominance of book culture in literacy education. In: M. Baynham \& M. Prinsloo (Eds.), The future of literacy studies. London \& New York: Palgrave Macmillan, pp. 141-159. 
WARSCHAUER, M. (1999). Electronic literacies: Language, culture, and power in online education. Mahwah, NJ: Lawrence Erlbaum Associates.

WARSCHAUER, M. (2002). A developmental perspective on technology in language education. TESOL Quarterly. v. 36, n³ 3, pp: 453-475.

WARSCHAUER, M. (2003). Tecbnology and social inclusion: Rethinking the digital divide. Cambridge, MA: The MIT Press.

WARSCHAUER, M. (2009). Digital literacy studies: Progress and prospects. In: M. Baynham \& M. Prinsloo (Eds.), The future of literacy studies. London \& New York: Palgrave Macmillan, pp. 123-140.

WARSCHAUER, M., \& WARE, P. (2008). Learning, change and power: Competing frames of technology and literacy. In: J. Coiro, M. Knobel, C. Lankshear \& D. Leu (Eds.), Handbook of research on new literacies. New York: Lawrence Erlbaum, pp. 215-240.

WENGER, E. (1998). Communities of practice: Learning, meaning and identity. Cambridge: Cambridge University Press.

Recebido: 29/01/2016

Aceito: 05/07/2016 